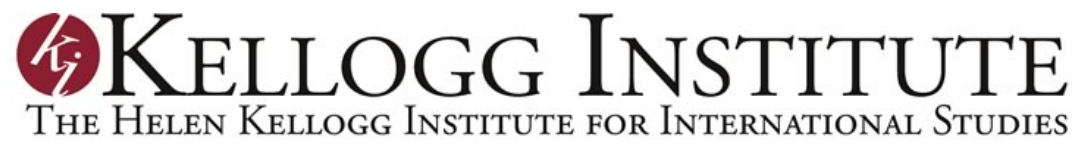

FROM "RESTRICTED" TO "BESIEGED":

THE CHANGING NATURE OF THE LIMITS TO DEMOCRACY IN COLOMBIA

Ana Maria Bejarano and Eduardo Pizarro Leongómez

Working Paper \#296 - April 2002 


\title{
FROM "RESTRICTED” TO “BESIEGED”: THE CHANGING NATURE OF THE LIMITS TO DEMOCRACY IN COLOMBIA
}

\author{
Ana Maria Bejarano and Eduardo Pizarro Leongómez
}

Working Paper \#296 - April 2002

\begin{abstract}
Ana Maria Bejarano holds a BA in Political Science from the Universidad de los Andes, and an MA, MPhil and PhD from Columbia University. Bejarano is an Assistant Professor of Political Science at the Universidad de los Andes. From 1998 until 2000, she also directed the Center for Socio-Legal Studies at that same University. She was a Research Scholar at the Kellogg Institute during the academic year 2000-2001. She is currently a Visiting Fellow at the Center of International Studies and also at the Program in Latin American Studies at Princeton University. Her work deals with the state, regime change, democratization and political institutions in Latin America. Her published works include Elecciones y democracia en Colombia: 1997-1998 (co-edited with Andrés Dávila) and "The Constitution of 1991: An Institutional Evaluation Seven Years Later" in Bergquist et al. (eds), Waging War and Negotiating Peace: Violence in Colombia, 1990-2000.
\end{abstract}

Eduardo Pizarro Leongómez currently a Visiting Fellow at the program in Latin American Studies at Princeton University, was a Visiting Fellow of the Institute for the academic year of 2000/01, and is a Professor at the Universidad Nacional de Colombia in Bogotá, where he has served as Director of the Instituto de Estudios Políticos y Relaciones Internacionales (IEPRI). He has published several scholarly analyses of the conflict in Colombia, including Las FARC (1949-1966): De la autodefensa a la combinación de todas las formas de lucha (Tercer Mundo Editores/IEPRI, 1991), and he is a weekly contributor to the national newspaper El Espectador. 
We are grateful for the comments of Scott Mainwaring, Frances Hagopian, Aníbal PérezLiñán, Diego Abente, Gretchen Helmke and Benito Nacif.

The authors are political scientists. Ana Maria Bejarano is a professor in the Department of Political Science at the University of the Andes and Eduardo Pizarro is a professor in the Institute of Political Studies and International Relations at the National University of Colombia. 


\begin{abstract}
During the last decade and a half, Colombia has witnessed both an improvement in the dimensions of democratic participation and contestation and a severe deterioration in those dimensions of democracy related to effective protection of civil liberties and subordination of the military. While the term "semi-democracy" seems most appropriate to classify the Colombian political regime, the restrictions that made the Colombian regime semi-democratic during the second half of the twentieth century have changed in nature. Between 1958 and 1986, restrictions were placed on the competitive dimension of democracy. From the mid-1980s onward, the regime's shortcomings stem from the weakness of the state, the emergence of powerful armed actors, and the absence of the rule of law.
\end{abstract}

Seeking to explain this recent process of democratic erosion, our argument hinges mainly on political variables, even as it takes into account the deleterious impact of drug trafficking on the Colombian state, society and politics. At the regime level, we claim that it is no longer the system's "closed" nature that affects prospects for democratic consolidation, but instead the excessively lax rules of the game created by the political reform initiated in the mid-1980s. This set of rules has engendered additional incentives for party fragmentation, leading to an extremely atomized and personalistic party system.

Yet at another level, we argue that the Colombian state has undergone a severe erosion leading to its partial collapse in the late 1980s. This collapse is partial in the geographical sense and also in the functional sense: while some state apparatuses have retained certain coherence and capacity to act, other crucial state branches have either collapsed, have become almost totally ineffective, or have become totally disfigured in relation to their original functions. This "partial collapse" of the state is the result of challenges posed by both guerrilla expansion as well as very powerful criminal organizations (the drugdealing cartels) upon a state which was historically weak to begin with.

\title{
RESUMEN
}

Durante la última década y media Colombia ha experimentado tanto una mejora en las dimensiones de participación y competencia democráticas como un severo deterioro en aquellas dimensiones de la democracia relacionadas con la protección efectiva de las libertades civiles y la subordinación de las fuerzas armadas. Si bien el término "semidemocracia" parece el más apropiado para clasificar al régimen político colombiano, la naturaleza de las restricciones que hicieron al régimen colombiano "semi-democrático" durante la segunda mitad del Siglo XX ha cambiado. Entre 1958 y 1986 existieron restricciones sobre las dimensiones competitivas de la democracia. A partir de mediados de los 80 s, los defectos del régimen derivan de la debilidad del estado, la emergencia de poderosos actores armados y la ausencia del imperio de la ley.

Procurando explicar este proceso reciente de erosión democrática, nuestro argumento se articula principalmente a partir de variables políticas, aún cuando toma en cuenta el impacto pernicioso del tráfico de drogas sobre el estado, la sociedad y la política colombianos. En el nivel del régimen, sostenemos que ya no es su naturaleza "cerrada" la que afecta las perspectivas de consolidación democrática, sino las excesivamente laxas reglas de juego creadas por la reforma política iniciada a mitad de los 80 s. Este conjunto de reglas ha engendrado incentivos adicionales para la fragmentación partidaria, llevando a un sistema de partidos extremadamente atomizado y personalista. 
En un nivel adicional, sostenemos que el estado colombiano ha experimentado una severa erosión que llevó a su colapso parcial hacia fines de los 80s. Este colapso es parcial en el sentido geográfico y también en el sentido funcional: mientras que algunos aparatos del estado han mantenido cierta coherencia y capacidad de actuar, otras ramas cruciales del estado han colapsado o bien devenido casi totalmente ineficaces o totalmente desfiguradas en relación con sus funciones originales. Este "colapso parcial" del estado es el resultado de los desafíos planteados tanto por la expansión de la guerrilla como por organizaciones criminales (carteles de tráfico de drogas) a un estado que era, en principio e históricamente, débil. 

Colombian democracy has always been a democracy with adjectives. ${ }^{1}$ Recently, the literature has replaced references to its "controlled" or "restricted" nature with descriptions of this democracy as "besieged" (Archer 1995) or "under assault" (Kline 1995). The shift in semantics is revealing. In this essay, we argue that Colombian democracy is still limited by a series of characteristics that merit the continued use of adjectives. Nevertheless, given that these limits have changed in nature, any adjectives used to characterize the current Colombian political regime must be fundamentally different from those employed during the three decades spanning 1958 to 1991.

As Collier and Levitsky have pointed out (1997: 432), a good description is indispensable to evaluating the origins and consequences of any political regime. We have adopted the term "besieged"2 to describe the current state of democracy in Colombia. While previous adjectives emphasized internal or endogenous limits on the political regime, this definition highlights exogenous factors-that is, external forces that make it impossible for democracy to function adequately. During the National Front period, democracy's limitations resulted from restrictions on political participation and political competition. In the present era, its limitations are rooted in the impact of various forces on democracy: the erosion of the state, the expansion of violence, and the rise of powerful extrainstitutional actors who constrain the space needed to consolidate a free democratic playing field.

\section{A Complex Classification}

Colombia's government is a civilian one, and elections have been held at regular intervals with little interruption since Gran Colombia's dissolution in 1830. The country thus retains the historical traits that led to its repeated classification as a democracy; that is, periodic elections have brought civilian rulers to power. ${ }^{3}$ Yet a closer look at current 
indicators reveals a number of paradoxes. True, elections are held on a regular basis-but leaders, candidates, and elected politicians are also regularly assassinated. The press is free from state censorship, but journalists and academics who make their opinions known through that press are systematically murdered. Electoral authorities recognize a growing number of political parties and minorities have increasing participation in representative bodies. The Colombian constitution recognizes these groups and the law makes the opposition's rights and responsibilities explicit. At the same time, the murders of opposition politicians multiply. For a century and a half, control of the state has been in civilian hands except for a few short, infrequent, and exceptional periods. Nevertheless, the military has retained a high degree of autonomy in matters of internal public order, as well as a series of prerogatives that place it above civilian control. The state claims that it alone can exercise legitimate use of force, while at the same time admitting its inability to contain one of the world's highest murder rates. Can this legitimately be called democracy?

In our opinion, it would be a misinterpretation to cross the border that separates democratic systems from nondemocratic ones and classify Colombia as an authoritarian regime. For that reason it seems appropriate to adopt the three-part classification proposed by Mainwaring, Brinks, and Pérez-Liñán (2001), which provides a clearer typology for borderline cases such as Colombia's. Based on quantitative indicators, Mainwaring (1999) and Altman and Pérez-Liñán (2000) show no hesitation in classifying Colombia as a semidemocracy since $1958,{ }^{4}$ with the exception of a short democratic period between 1974 and 1990 (See Table 1).

The authors present quantitative data that is useful for dating and describing important changes in political regimes that are generally classified as democratic. Yet it is important not only to date and describe processes of change, but also to understand their nature. It therefore seems worthwhile to point out that, at least in the Colombian case, the 
nature of restrictions has changed from one semidemocratic period to another. Mainwaring (1999), for example, correctly classifies the Colombian regime as "semidemocratic" in two different periods of its contemporary history (see Table 1$)^{5}$ The problem lies in the lack of differentiation between these two periods, which in our judgment seems critical. While the first period (1958-1974) was fundamentally characterized by restrictions on competition resulting from the 1957 institutional pact, restrictions during the second period (1990-1997) are related to the Colombian state's inability to guarantee basic civil rights and liberties.

Table 1

\begin{tabular}{c|l}
\hline \multicolumn{2}{c}{ Classification of Latin American Governments, 1940-1997: Colombia } \\
\hline Period & Classification \\
\hline $1936-1949$ & Semidemocratic \\
$1949-1957$ & Authoritarian \\
$1958-1974$ & Semidemocratic \\
$1974-1990$ & Democratic \\
$1990-1997$ & Semidemocratic \\
\hline
\end{tabular}

Adapted from Scott Mainwaring, Table 1 (1999: 16)

Rather than unify in a single index the multiple dimensions that are critical to democracy, it seems best to consider each dimension separately in order to distinguish clearly the nature of threats to, and limitations on, our democracies. The measurement approach offered by Freedom House ${ }^{6}$ is an example that can be applied to the Colombian case. Looking carefully at Table 2, it is clear that while the country's general rating has worsened notably since 1989-90, the deterioration of civil liberties was more marked and sustained than that of political rights. In fact, the latter dimension presents variations that are difficult to interpret as an unmistakable worsening trend: there have been improvements after 1991 and irregular variations since 1994. 
TABLE 2

\section{Colombia: Freedom House Scores}

\begin{tabular}{|c|c|c|c|c|}
\hline Year & Political Rights & Civil Liberties & Combined Index & Status $^{\star *}$ \\
\hline $1972-73$ & 2 & 2 & 4 & $\mathrm{~F}$ \\
\hline $1973-74$ & 2 & 2 & 4 & $\mathrm{~F}$ \\
\hline $1974-75$ & 2 & 2 & 4 & $\mathrm{~F}$ \\
\hline $1975-76$ & 2 & 3 & 5 & $\mathrm{~F}$ \\
\hline $1976-77$ & 2 & 3 & 5 & $\mathrm{~F}$ \\
\hline $1977-78$ & 2 & 3 & 5 & $\mathrm{~F}$ \\
\hline $1978-79$ & 2 & 3 & 5 & $\mathrm{~F}$ \\
\hline 1979-80 & 2 & 3 & 5 & $\mathrm{~F}$ \\
\hline $1980-81$ & 2 & 3 & 5 & $\mathrm{~F}$ \\
\hline 1981-82 & 2 & 3 & 5 & $\mathrm{~F}$ \\
\hline $1982-83$ & 2 & 3 & 5 & $\mathrm{~F}$ \\
\hline $1983-84$ & 2 & 3 & 5 & $\mathrm{~F}$ \\
\hline $1984-85$ & 2 & 3 & 5 & $\mathrm{~F}$ \\
\hline 1985-86 & 2 & 3 & 5 & $\mathrm{~F}$ \\
\hline $1986-87$ & 2 & 3 & 5 & $\mathrm{~F}$ \\
\hline 1987-88 & 2 & 3 & 5 & $\mathrm{~F}$ \\
\hline 1988-89 & 2 & 3 & 5 & $\mathrm{~F}$ \\
\hline $1989-90$ & 3 & 4 & 7 & PF \\
\hline $1990-91$ & 3 & 4 & 7 & PF \\
\hline 1991-92 & 2 & 4 & 6 & PF \\
\hline 1992-93 & 2 & 4 & 6 & PF \\
\hline 1993-94 & 2 & 4 & 6 & PF \\
\hline 1994-95 & 3 & 4 & 7 & PF \\
\hline 1995-96 & 4 & 4 & 8 & PF \\
\hline $1996-97$ & 4 & 4 & 8 & PF \\
\hline 1997-98 & 4 & 4 & 8 & PF \\
\hline 1998-99 & 3 & 4 & 7 & PF \\
\hline 1999-00 & 4 & 4 & 8 & PF \\
\hline
\end{tabular}

${ }^{*}$ Combining Freedom House's two types of ratings in a single index, Mainwaring creates a scale that goes from 2 (best performance) to 14 (worst). Democracies are usually rated between 2 and $5 ; 7$ corresponds to his category of semidemocratic governments; authoritarian regimes fall between 9 and 14; numbers 6 and 8 denote borderline cases with the former between democracy and semidemocracy and the latter between semidemocracy and authoritarianism (Mainwaring, 1999: 22).

**The designation of "status" as "free" (F), "partially free" (PF) or "not free" (NF), which is the result of the combination of the measurement of political rights and civil liberties, indicates the general degree of freedom in a country or territory. 
Among the alternative typologies proposed by Collier and Levitsky (1997), the sub-type of "illiberal" democracy perhaps best defines the current situation of Colombian democracy. This alludes to the absence of a state capable of guaranteeing the constitutional order-that is, the absence of a rule of law that makes the liberal dimension of modern democracy possible. ${ }^{7}$ Colombia clearly constitutes a democracy whose faults are not to be located at the level of the typical dimensions of a polyarchy (participation and opposition, according to Dahl, 1971), but whose main failure is related to the lack of the rule of law. ${ }^{8}$ Based on the preceding discussion, we propose to reformulate the classification of Colombia's political regime during the twentieth century as follows:

The current situation of Colombia's democracy can be conceived, therefore, as a game being played on two fields simultaneously. There is an electoral field (where the rules of the democratic game are largely respected among legally recognized political actors) and an extra-institutional field (where the rules of war rather than the rules of democracy apply, including the accumulation of instruments of force, such as men, territory, and arms). The electoral game is in a way "suspended" over the field of extrainstitutional forces, which have a powerful impact on its outcome. This occurs not only because of the interconnections between institutional and extra-institutional actors, but because the space available for the electoral game depends upon expansion or contraction of the space designated for the second game: war. For this reason we have adopted the metaphor of "besieged democracy." 
Table 3

\begin{tabular}{c|c|c|c|c}
\hline \multicolumn{5}{c}{ Colombia: Classification of twentieth-century political regimes } \\
\hline Period & $1910-1949$ & $1949-1958$ & $1958-1974$ (1986) & $1985-2000$ \\
\hline Missing Attribute & Full Suffrage & All & Full Contestation & Civil Liberties \\
\hline Democratic & "Oligarchical" & None & "Restricted" & "Besieged" (Illiberal) \\
Subtype & Democracy (a) & (Authoritarian) & Democracy (b) & Democracy (c) \\
\hline
\end{tabular}

a). The original concept is from Alexander Wilde (1982).

b). The original concept is from Francisco Leal Buitrago (1984).

c). The original concept is from Ronald Archer (1995).

\section{2. "Not all good things go together..."}

As the Freedom House data suggest in the Colombian case, it is possible that the various dimensions associated with democracy may evolve to follow variable rhythms and sometimes, opposing directions. Consequently, it is less appropriate to speak of advances and setbacks for democracy as a whole, since one case can demonstrate advances in some directions alongside setbacks in others. Another complicating factor, as we will see later, is that efforts to improve some critical aspects of democracy (such as electoral reforms) can end up having a negative impact on other important dimensions (such as governability).

Four attributes constitute the core of the contemporary consensus about democracy understood in procedural terms. These attributes are: 1) inclusion of the majority of the adult population through universal suffrage; 2) selection of top political leaders (president and parliament, at least) through competitive, free, clean, and regular elections; 3) respect for and effective protection of civil rights and liberties; 4) the ability of elected authorities to govern without being subject to external controls or vetos by 
nonelected actors (such as the military). ${ }^{9}$ Nevertheless, as the Colombian case illustrates so well, the holding of competitive and fraud-free elections in which the whole adult population has the right to participate is not always accompanied by the other essential attributes of democracy.

Colombia attained the first of these requirements (universal suffrage) during the 1957 plebiscite, when women had the right to vote for the first time. The second attribute, which deals with the nature of elections, suffered serious restrictions between 1958 and 1974, especially with regard to political competition. Since the National Front pacts not only excluded third parties but also limited competition between the two majority parties (Liberal and Conservative), the regime at the time has been correctly described as semicompetitive, restricted, or limited. ${ }^{10}$

The situation between 1974 and 1986 is difficult to define with any precision, since the majority of formal restrictions on the government were lifted when the National Front period ended. ${ }^{11}$ At the same time, many informal restrictions remained that were the inescapable legacy of the limits placed on the democratic playing field. From 1986 onward (with the decision of Virgilio Barco's government to put together an exclusively Liberal administration and the Conservatives' concomitant decision to oppose it as a single party), the last of the remaining restrictions related to elections and government composition fell away. Delegates to the 1991 Constituent Assembly legalized this situation, and the new constitution ratified that year finally eliminated the formal vestiges inherited from the National Front pacts.

Simultaneous to these political reforms, between 1989 and 1994 successful negotiations took place with all of the second-generation guerrilla movements ${ }^{12}$ (including the April 19 Movement, or M-19; the Revolutionary Workers' Party, or PRT; the Quintín Lame Armed Movement, or MAQL; and the Socialist Renovation Current, or CRS) and with an important group that had appeared during the 1960s (the Popular 
Liberation Army, or EPL). ${ }^{13}$ As a result of these negotiations, some 4,000 combatants were reincorporated into civilian life (Palacios, 2000: 362).

Consequently, from the beginning of the 1990s we can speak of the existence in Colombia of a democracy that-unambiguously and completely-meets the first two requirements of any contemporary definition of democracy: broad participation and free competition. ${ }^{14}$ From that time on it is impossible to argue for the political regime's classification as some subtype of authoritarianism. It seems best, instead, to classify it as a subtype (albeit "diminished") of democracy. ${ }^{15}$

In spite of these advances, Colombia has not been able to achieve the consolidation of a full democracy. Despite efforts to incorporate armed rebels and to broaden the legal political space, the political regime has deteriorated since the mid1980s. Yet the nature of democracy's erosion during the most recent period is, as we have argued, fundamentally different from that experienced by the regime during the period that began with the National Front. The causes of the current situation are found primarily in the state's inability to effectively guarantee civil rights and liberties. If we can speak of a crisis of democracy in Colombia, it is because of the deterioration of the last two basic attributes of democracy rather than those related to elections.

Any discussion of respect for and effective protection of civil rights and liberties ${ }^{16}$ must begin with a look at the country's human rights situation, which demonstrates the state's growing inability to protect its citizens and guarantee the effective exercise of their rights and freedoms. "In Colombia, between October 1999 and March 2000, nearly 14 persons per day were victims of sociopolitical violence, on average: more than eight of these were victims of extrajudicial executions and political homicides; close to one was forcibly disappeared; there was one homicide every two days committed against socially marginal persons; and more than four people died in combat each day" (Colombian Commission of Jurists, 2000: 9). Between 1994 and 1998, the annual 
average of homicides reached approximately 26,000. During the same period, 7,022 people were kidnapped. In addition, approximately 1,350,000 people were forcibly displaced between 1985 and $1998 .{ }^{17}$

On the other hand, when speaking of the capacity of elected officials to govern effectively, we can affirm that Colombia does not deserve any of the adjectives used to describe facade democracies - in which the military holds the real power over civilian puppets—such as "guarded," "protected," or "tutelary" democracy. As is well known, the Colombian military has not occupied the political center stage for a number of reasons that will not be analyzed here. ${ }^{18}$ Yet even though the military has not completely obstructed the civilian government's ability to govern, since 1958 it has had a wide degree of autonomy and an increasing number of prerogatives. Specifically, the Colombian military has enjoyed a great deal of latitude in defining policies for external defense and internal security, both of which have become critical areas given the situation of prolonged internal conflict.

Rather than apply the term "tutelary democracy" to the Colombian case, it seems better to employ Samuel Valenzuela's conceptual proposal (1992), which highlights the military's "tutelary powers" and "reserved domains" as perverse elements impeding the consolidation of democracy. These prerogatives and reserved domains grew as the war expanded and the military's involvement in antidrug efforts increased. ${ }^{19}$ The process became evident from 1977 onward $^{20}$ and continued without pause during the Turbay Ayala administration (1978-1982). Efforts by the next three governments (Betancur, Barco, and Gaviria) to subordinate the military were unsuccessful and were finally reversed during Ernesto Samper's administration which, attempting to avoid a coup at any cost, made numerous concessions to the military.

In Colombia, then, two contradictory tendencies have been at work simultaneously: a tendency toward greater democratization-which includes the 
elimination of prior restrictions and the broadening of the space for political participation and competition - and a tendency toward deterioriation of the indicators of "civility," of respect and protection of basic civil rights and liberties. ${ }^{21}$ That said (and despite our argument that the central problems of Colombian democracy relate to accountability and civil rights and liberties) we realize that the latter factors have had a negative impact on the components of participation and competition that are typical in any democracy. Neither competition nor participation can be complete in a context of widespread armed conflict, as is the case in Colombia. Even though massive electoral fraud does not exist, distortions in the electoral process-especially at the local and regional levels - are very serious, precisely for the reasons noted above. Since the end of the 1980s, and especially since the first popular election of mayors (1988), local and regional elections have been increasingly subject to limitations on competition resulting from the actions of different types of armed actors who seek to capture and control territory and people. ${ }^{22}$ Simultaneously, the electorate's ability to vote "freely" (that is, free from fear and/or coercion) has also diminished as the areas controlled by one armed actor or another has increased and above all, where armed actors compete bitterly to control territory and people. Violence distorts democracy's participatory and competitive dimensions, both before and after elections. Numerous Colombian government officials have been assassinated following their election. According to Echandía (1999b), 138 mayors and 569 members of parliament, deputies, and city council members were assassinated between 1989 and 1999, along with 174 public officials in other positions.

It is difficult to pinpoint an exact date or specific event that marked the beginning of this contradictory process of democratic erosion. In contrast with other cases where an attempted military coup, popular insurrection, or some other major event led to a crisis, Colombia has witnessed a process of gradual erosion, rather than sudden breakdown of democracy. ${ }^{23}$ The process began in the mid-to-late 1980 s, although some prefer to 
pinpoint its origins between mid-1989 and mid-1990. ${ }^{24}$ In Coppedge and Reinecke's analysis of the year 1985, Colombia is classified as a democracy (1990: 63). Some years later, Mainwaring classified Colombia as a "semidemocracy," marking the point of change at 1990 (1999: 16). Freedom House's data indicate that the passage from "free" to "partially free" status took place between 1989 and 1990. If we rely on Hartlyn and Dugas's judgment (1999), the period of crisis encompasses the last fifteen years, with some ultimately failed attempts at recuperation in the early 1990s. After fifteen years of steady deterioration, perhaps the most surprising aspect of the Colombian case is not the fact that democracy is in crisis, but that it has survived at all given the very formidable political rather than structural or economic challenges confronting it.

\section{Explaining the Erosion of Colombian Democracy}

In his article "Democratic Survivability in Latin America," Scott Mainwaring (1999) argues that three factors help explain the vicissitudes of democracy in Latin America, including the fact that the majority of the region has become democratic since 1978 (1999: 12). The first factor relates to structural transformations unleashed by modernization. Social and economic changes related to the urbanization process, the increase in literacy, the growth of the working and middle classes, and the reduction of the power of the land-owning class have provided in Colombia and throughout the continent—fertile ground for the growth of more democratic forms of government. Mainwaring's third factor, related to growing international support for democracy, has also contributed to the emergence of democratic regimes in Latin America and in the rest of the world. These two factors have helped to build the pillars on which Colombian democracy has rested despite the twin threats of insurgent victory and military coups. 
Mainwaring argues that the second factor favoring democracy became evident during the 1980s, when Latin American political attitudes changed (both on the left and the right ends of the political spectrum). Democracy became more valued, and the political environment became less polarized than it had been in the 1960s and 1970s (1999: 12). To support his thesis the author documents an important change in attitudes toward democracy, especially among leftist political actors throughout the region (1999: 42-43). It is perhaps here that Colombia has distanced itself radically from other countries of the region. In the Colombian case, five guerrilla groups were re-incorporated to civil society between 1990 and 1994, but notably, two groups remained active (the Revolutionary Armed Forces of Colombia, or FARC, and the National Liberation Army, or ELN). Far from changing their views of democracy and revolution, these two groups deepened the more radical aspects of their discourse and their perception of reality. This radicalization not only robbed the moderate, legal Left of political space; it also produced an equally extreme radicalization of the Right, which expressed itself not through a legal political party but through multiple "paramilitary" groups. Consequently this factor, which favored democracy's establishment and maturation in the rest of Latin America, has evolved in the opposite direction in Colombia.

Of the three factors that Mainwaring cites as important (1999), the first (economic modernization) and the second (international factors) serve to explain the resilience of Colombian democracy despite the adverse conditions it has faced. At the same time, the second factor (attitudes of political actors) may be one possible cause explaining the erosion of Colombian democracy. In Colombia, the existence of increasing ideological polarization has undoubtedly had a negative impact on the political regime. Yet this factor alone seems insufficient to explain the regime's dramatic erosion and failure to meet some of the fundamental requirements of any democracy. 
Some authors have sought to explain the erosion of Colombian democracy with cultural arguments. Not many have volunteered macroeconomic explanations since it is obvious that the Colombian political crisis is the cause, rather than the consequence, of the recent economic crisis. Undeterred, others have insisted on highlighting inequality and poverty as structural impediments to democracy. Still others have blamed the drug trade and its effects as the cause of all ills. Without discounting the multifaceted nature of the current crisis, we would like to propose a fundamentally political explanation that is based upon a set of variables related to both the regime and the state. The first set of variables highlights the defects, vacuums, and institutional distortions inherent in the political regime. The second set focuses on aspects associated with the state, emphasizing its historic weakness, its recent erosion, and its partial collapse.

\section{a) The crumbling of the system of political representation}

From its beginnings in 1958, critics decried the bipartisan institutional arrangement of the National Front as antidemocratic. Alfonso López Michelsen ${ }^{25}$ was undoubtedly the first to criticize the National Front pacts. López Michelsen was the founding leader of a dissident faction of the Liberal Party (the Liberal Revolutionary Movement, or MRL), which grew out of opposition to the rules of the game imposed by the 1957 plebiscite and the Legislative Act of 1959, which required alternating control of the presidency. The Communist Left was at first ambivalent, but quickly became very critical of the restrictions that grew out of the agreement, and in particular of the exclusion of third parties from political competition. ${ }^{26}$ As a result of the electoral fraud allegedly committed against the National Popular Alliance (ANAPO) in the 1970 elections, criticism of the National Front's institutional arrangement became more radical. Many joined the ranks of the armed Left with the argument that they had been excluded from access to the state through institutional channels. ${ }^{27}$ 
Throughout the 1970s and 1980s, social scientists appropriated this critique of the restrictions on government. ${ }^{28}$ Reform of the regime became a shared cause among leftists, intellectuals, and reformist politicians. Many diagnoses of the democratic crisis and of Colombia's armed conflict were based on the argument of "restricted democracy" or the idea that while the regime was democratic in the formal sense, the remnants of a series of exclusionary practices still prevailed informally. Inherited from the National Front, such practices restricted free competition and gave traditional parties a near-monopoly on political life, closing off any possibility for the emergence and consolidation of a democratic leftist opposition. The proposals for reform that proliferated during the $1980 \mathrm{~s}$ (many of which grew out of peace negotiations with the guerrillas) had their roots in this diagnosis, and without a doubt they served as the cornerstone of the constituent process of 1991. A central objective of the 1991 constitution was to dismantle the restrictions on Colombian democracy once and for all.

From the time of the political reforms approved in the mid-1980s until the ratification of the 1991 constitution, the rules of the political game were fundamentally transformed, allowing an opening in the channels of access to power that led to a broader representation of society in the state. All formal restrictions on government were abolished with the 1991 reform, allowing the establishment of an extremely lax system that placed almost no institutional barriers at the entry. The opening of the channels of political representation at a time when the two-party system was showing signs of exhaustion was one positive effect of the 1991 constitutional reform. The extreme atomization of political representation was an important negative effect. The overall result of reforms is therefore ambiguous.

Today, it seems impossible to argue that restrictions on the political regime are the source of the problems of democracy in Colombia. It is also unconvincing to maintain that informal rules of the game or specific political practices (clientelism, patronage, and 
other types of "particularlism" "29) undermine the regime's democratic character, as some authors have maintained following the thesis of Leal (1984) and later Leal and Dávila (1990). Evidently, such restrictive practices and their frequency affect the "quality" of democracy. Yet undesirable as they are, the mere existence of particularistic practices does not prohibit the possibility of classifying the Colombian political regime as democratic. $^{30}$

The principal element related to institutional design that can in some way explain the recent crisis is associated not with "restrictions" but with the excessive opening that began in 1991. The pendulum has swung to the opposite side. The "logic of incorporation", ${ }^{31}$ taken to an extreme with the 1991 reforms, led to the design of an extremely lax party and electoral system that produced enormous disorganization among parties (both new and traditional) and, as a consequence, in the system of political representation. ${ }^{32}$ Of course it can be argued that Colombian parties have always lacked organization and discipline, and that their tendency toward dispersion and fragmentation is nothing new. This is true. The argument is more valid if we point out that the institutional reforms that took place from 1991 onward-and above all, those related to the electoral system and the party statute-sharpened these historical tendencies among Colombian parties by creating additional incentives for fragmentation and atomization. These incentives have been so strong that they have even led third forces (that is, the new political parties and movements that grew out of the opening of the regime) $)^{33}$ in this direction.

This example illustrates the paradoxical situation in which efforts to strengthen democracy can have perverse and unexpected results that contribute to its erosion rather than consolidation. As Table 4 demonstrates, both the number of political parties and movements registered with the National Electoral Council and the number of lists of candidates for Senate and Chamber of Deputies have increased dramatically in the last 
decade. The situation has given rise not to a diffuse multiparty system (as in Ecuador) but to an attenuated (and highly atomized) two-party system, accompanied by a motley collection of "third forces" (which are highly fragmented).

Table 4

Number of Parties and Lists of Candidates Presented for Elections in Senate and Chamber of Deputies

(1990-1998)

\begin{tabular}{c|c|c|c}
\hline Year & Number of Parties & Number of lists for Senate & $\begin{array}{c}\text { Number of list for } \\
\text { Chamber of Deputies }\end{array}$ \\
\hline 1990 & 8 & 213 & 351 \\
1991 & 22 & 143 & 486 \\
1994 & 54 & 251 & 628 \\
1998 & 80 & 319 & 692 \\
\hline
\end{tabular}

Source: Pizarro and Bejarano (2001).

The consequences of this disarray among parties and in the party system have been disastrous for effective governance, particularly because it is impossible to obtain minimal party discipline at the various levels of political representation (Congress, departmental legislatures, or municipal councils), and because of the relative autonomy of each of the many dozens of "electoral micro-enterprises" that have captured the country's representative political space. In Colombia, party-based lists and partyappointed candidates are gradually disappearing, with the increasingly limited exception of candidates for the presidency of the republic. This atomization has not only generated enormous obstacles to coordination between the executive and legislative branches and made the task of governance much more difficult, it has also impeded the formation of a coherent opposition with the capacity to oversee the government and succeed it in power. The result has been a gradual undermining of the quality of democracy. 
In another context, perhaps, the weakening of parties and the system of party representation might have been considered simply a trade-off in exchange for the opening that began in 1991. Nevertheless, at times when the drug trade and paramilitary and farLeft groups have intensified their siege of Colombian democratic institutions, the disorganization of political society has contributed in large part to their erosion. Since the mid-nineteenth century, the Colombian state has compensated for its weakness, at least partly, by exercising indirect control at the local and regional levels through political parties. ${ }^{34}$ In this sense, the weakening of the political parties and of their tight links to society constitute one more dimension in which the Colombian state seems to have lost control over the country.

\section{b) Erosion and "partial collapse" of the state}

We now turn to the second part of the argument, which uses as a central explaining variable the Colombian state's growing inability to enforce a normative order that allows a set of democratic rules of the game to function adequately. The problem of Colombian democracy should not be located solely in the most visible dimension of its political regime, but at the level of its foundation, in the place where every democracy finds indispensable support: that of the effective exercise of rights and basic political and civil liberties. These rights and liberties are violated daily by each and every one of the armed actors participating in the violence that has shaken the country for two decades. The common cause of these violations is the loss of the Colombian state's coercive and normative capacities - that is, the collapse of that part of the state which must guarantee the effective exercise of full citizenship throughout the national territory.

The state's inability to provide a series of fundamental public goods-in particular, security and justice-limits the political regime's performance as a democracy and inhibits its capacity to carry out the promises of greater equality and freedom, 
effective representation and universal participation. As inappropriate use of force or simple threats by state or nonstate actors become widespread, fewer people participate in elections. Even when they participate, the result of the electoral process is distorted either because of threats before or assassinations after elections. At the same time, the proliferation of armed actors and their threatening capacity reduces the presence of alternative parties, and when the latter dare to compete they are eliminated, either before or after elections. The situation leads to a vicious circle that has terribly pernicious effects on democracy. In the absence of necessary guarantees, experiments aimed at broadening democracy can lead to greater levels of violence. This is especially true if the opening of spaces that were previously closed to political competition (the popular election of mayors, for example) provides a new incentive for the state's rivals to extend and deepen strategies to control territory and population.

It is important to point out that in the Colombian case we are talking about erosion, and not simply weakness, of the state. A weak state has been a constant in Colombian history. For that reason, it is worthwhile to highlight the difference between arguments that insist upon the Colombian state's weakness or precariousness (as a constant) and those that document its recent erosion. The former are insufficient to explain recent variations in the political regime. The notion of erosion takes into account a process that is progressive and more recent. We would argue here that, after a period of relative strengthening that began during the National Front (Bejarano and Segura, 1996), since the 1980s the Colombian state has undergone a progressive process of deterioration and erosion to the point of reaching what we can classify as a "partial collapse." 35

Second, it seems important to highlight the adjective "partial." By no means do we intend to argue that the Colombian state has suffered a total or definitive collapse, as was the case in countries such as Somalia and others used to illustrate what contemporary analysts describe as "failed states." 
that some crucial state apparatuses, especially those responsible for protecting citizens (the police and judicial branches, for example) have eroded to the point that they are fundamentally unable to carry out their basic functions. ${ }^{37}$

In addition, the use of the term "partial" to describe the process of collapse of the state indicates the state's inability to reach and control some areas of national territory. The Colombian state has always been absent in some regions. Geographers, sociologists, and historians have widely documented this fact, especially those studying areas of recent settlement. ${ }^{38}$ Yet it is also true that the state's precarious reach has "contracted" even further in recent decades, as a result of the ability of other armed groups (guerrilla and paramilitary) to occupy and control growing portions of national territory. In some cases, the state has given up its normative and coercive monopoly and nearly delegated the performance of some basic functions to right-wing armies, such as the United SelfDefense Groups of Colombia (AUC) in northern Antioquia and Cordoba. In other areas, "enemy" armed groups (guerrillas) have seriously challenged state control, as is the case in jungle areas where illegal cultivation of cocaine takes place. Finally, since 1998 and as a result of the negotiations at the time, the government ceded control of five municipalities - spanning 42,000 square kilometers-to the FARC's central command (the so-called "demilitarized zone"). This process of contraction of the state's presence and authority in Colombia can be represented as a rapid process of expansion of the "brown areas" defined by O’Donnell (1999a: 139), or places with a very low or nonexistent state presence in territorial, functional, or class terms.

By contrast with O'Donnell's description of the Argentinian, Brazilian, and Peruvian cases (1999a), the state's partial collapse in Colombia is not associated with the patterns of capital accumulation, nor with the crisis of the state-centered matrix described by Cavarozzi (1991), nor with the adjustments imposed by economic globalization that are commonly associated with the surge in neoliberalism. The Colombian case is instead 
one in which the erosion of the state apparatuses charged with providing defense, security, and the protection of its citizens has resulted in its losing the monopoly on coercion and justice. To this is added, as a corollary, the emergence of powerful nonstate actors that challenge that state's monopoly and its control over the territory and the population.

It is true that the Colombian state, from an historical and comparative perspective, has been small, poor, and weak. ${ }^{39}$ There are three historic causes of the Colombian state's weakness: the country's vast territory and difficult geography; a weak, outward-directed economy that produced practically no internal market until the end of the nineteenth century; and finally, the nation's precarious identity, marked by very strong and deep regional and party divisions. Yet the state's weakness cannot be assumed as an unchanging and inevitable fact of reality. The process of state-building does not follow a linear path; like any social process, it included ups and downs, advances and setbacks. The so-called era of Violencia was one of deterioration and crisis of the state authority that had developed during the first half of the twentieth century. With the National Front, a process of reconstruction and selective strengthening began (Bejarano and Segura, 1996) that would last throughout the 1960s and 70s. During the 1980s, a process of rapid erosion took place that was caused by more contemporary factors. Among these was the prolongation of the internal armed conflict and the challenge presented by the drug trade. The impact of this "double war"- the extenuating combination of the war against the guerrillas and the war on drugs—-superimposed on a chronically weak state, explains its partial collapse at the end of the 1980s.

The guerrilla war began in Colombia-in contrast with the rest of Latin America-in the decade prior to the Cuban revolution. ${ }^{40}$ Unlike their counterparts in the rest of the continent, Colombian guerrilla forces avoided annihilation and managed to consolidate during the 1970s. Their consolidation is, in itself, evidence of the chronic 
weakness of the Colombian state. Yet beyond the guerrillas' emergence and eventual consolidation, the factor that best explains the more recent erosion of state authority is the weakening produced by more than three decades of internal armed conflict. The enormous resources that the state has devoted to counterinsurgency-along with the organizational and budgetary distortions caused by maintaining a fighting army for more than thirty years-partly explain the current configuration of the Colombian state, the overgrowth of the armed forces, and the abandonment of other crucial branches of government, such as the judiciary.

In addition to the prolonged guerrilla war, it is important to note the lack of consensus among the political, economic, and military elites about how to deal with the armed opposition. As Mauceri has affirmed (2001), the absence of a coherent political project shared among the elites is perhaps one historic cause of the Colombian state's weakness. In more recent times, this lack of inter-elite consensus has become even more evident, especially with regard to maintenance of public order. During the Betancur administration (1982-86), the president's approach to the peace process divided elites into at least two camps. While some sectors sought a negotiated end to the armed conflict, others have chosen to privatize and decentralize the counterinsurgency war, to support paramilitary groups, and to disregard the fact that such efforts compete with the state's central role. ${ }^{41}$ Moreover, within the Colombian state itself some sectors have sought a political end to the conflict, while others have offered legal protection and logistical support to private groups (paramilitary, self-defense, and other private vigilante groups) that allow them to develop their privatized insurgent strategy without impediment. Clearly, the so-called paramilitary groups are the product of an abdication of power by some sectors of the Colombian state.

The 1980s also witnessed the expansion of the drug trade in the Americas and the growing role of Colombian business in transnational drug networks. Undoubtedly, the 
drug trade has an important place in explaining the Colombian crisis. Yet it should not be examined alone, as a phenomenon that is exogenous to politics, but for its multiple economic, social, and political ramifications and its particular impact on the process of state erosion. The groups involved in the drug trade have had a devastating effect on Colombian society and politics. ${ }^{42}$ On the one hand, the leaders of the drug trade have sought to translate their enormous fortunes into political influence and they have gained access to decision-making power by multiple routes. They have created their own electoral machines, ${ }^{43}$ participated openly in traditional parties, ${ }^{44}$ financed election campaigns, ${ }^{45}$ and wielded enormous power in local elections. On the other hand, to combat the state's antidrug policies they have resorted to all sorts of tactics: from bribery and corruption to threats, assassination, and an indiscriminate use of terror. ${ }^{46}$

In addition, the profits produced by drug trafficking have provided funds for all kinds of armed actors. Resources from the drug trade have financed the expansion of traffickers' private armies as well as the plans of paramilitary and guerrilla groups. The drug bonanza changed the magnitude of the conflict, because the drug trade became an inexhaustible source of funds for both paramilitary and guerrilla groups. It sharpened the tendency toward fragmentation among political actors and increased the degree of autonomy enjoyed by those who were in charge of the war-undoubtedly worsening the process of erosion of the state apparatus. Thanks to the drug trade, the state has seen its capacity diminish not only in absolute terms (as a result of corruption, threats, and the use of force) but also in relative terms. Drug money has allowed the state's rivals to expand their reach and operational capacity while the state's own power shrank.

At the same time, since the beginning of the 1980s the United States' antidrug policies in the Andean region have been the most important contributing international factor to the deterioration of state authority in Colombia. ${ }^{47}$ This policy, which aimed to cut off the supply of drugs from South America using the United States' uncontestable 
power in the region, has limited the autonomy of the Andean states and made it impossible for them to design alternative strategies for combating the production and trade of drugs. Perhaps the most perverse effect of the policy, in the Colombian case, has been the increasing militarization of the fight against drugs (involving first the police and now the army). This militarization has placed additional pressure on the state to increase the resources, prerogatives and hardware available to the military, in detriment to support for other key branches of government such as the judiciary. ${ }^{48}$ Imbalances within the state became deeper as a result.

Facing these multiple challenges, the state has also suffered the unexpected and unwanted effects of reforms aimed at opening the political system that began in the mid1980s. The erosion of parties and weakening of political society, described above, was one such effect. Decentralization has also weakened the state's power and returned it to actors who control regional and local governments, among them-in some regions-the enemies of the state (guerrillas and drug traffickers). Partly because of the transfer of resources from the center to the periphery ordered by the 1991 constitution, the fiscal deficit has seriously deepened. Finally, the executive branch has also seen its power diminish with the strengthening of Congress and the courts since 1991. These reforms, which were desirable and convenient to the degree they democratized the regime, have nevertheless led to limits and difficulties for the state as it has attempted to recuperate and affirm its power and centrality throughout the country.

Paradoxically, the 1991 constitutional process was part of an attempt by reformist elites to recuperate a minimum of state coherence and efficiency while at the same time democratizing the regime. ${ }^{49}$ Yet despite the efforts made in the early 1990 s, the crisis that unfolded during the Ernesto Samper administration (1994-98) deepened a process of state deterioration that has not yet ended. This deterioration is evident in two processes that are advancing simultaneously and which feed upon each other: the loss of the state's 
monopoly on violence and the loss of the state's normative centrality in society. As a result of both tendencies, a multiplicity of groups of diverse ideological persuasions has expanded and consolidated. These groups-guerrillas and paramilitary organizations-have emerged as rival "proto-states" of sorts, who accumulate power thanks to their capacity to provide basic services which by definition the central state should render: protection and justice.

c) The loss of the state's monopoly on violence

One of the most dramatic and common indicators used to demonstrate the process of state erosion in Colombia is the number of homicides. As Posada-Carbó has pointed out, "Where the weakness of the Colombian state appears most evident is in its manifest incapacity to provide security. Certainly, the Colombian state fails the Weberian test: it cannot make any successful claim to the 'monopoly of the legitimate physical force.' With the highest homicide rate in the world [...] the state is far from performing its most basic duty: to guarantee the right to personal security" (1998: 8).

In 1960, when the Violencia came to an end, Colombia still had the highest rate of nonaccidental deaths in the world (see Table 5).

Table 5

International Nonaccidental Death Rates

\begin{tabular}{l|c|c}
\hline Country & Year & Rate per 100,000 Inhabitants \\
\hline Colombia & 1960 & 34.0 \\
Mexico & 1958 & 31.1 \\
Nicaragua & 1959 & 22.8 \\
South Africa & 1959 & 21.2 \\
Burma & 1959 & 10.8 \\
\hline
\end{tabular}

Source: Paul Oquist (1978: 11) 
Around the mid-1960s the homicide rate decreased, reaching an annual level of 20 homicides per 100,000 inhabitants. It remained relatively stable at that point until the beginning of the 1980s. Between 1963 and 1983, the homicide rate per 100,000 inhabitants averaged 24.8. Since the mid-1980s, the homicide rate experienced a dramatic increase and reached a new peak of about 80 homicides per 100,000 inhabitants in 1991 . Since that time it has decreased only slightly. ${ }^{50}$

According to a report by the Institute of Legal Medicine and Forensic Sciences, “approximately 500,000 people, the majority civilians, died violently in Colombia during the last two decades. [...] The figure is equivalent to more than 1 percent of the current Colombian population, which is estimated at 41 million" (El Tiempo, October 13, 2000). ${ }^{51}$ Viewed in absolute terms, statistics on violent death in Colombia are undoubtedly alarming (see Table 6). Between 1970 and 1980, the number of violent deaths doubled. The figure doubled again around 1987— that is, in 1987 there were four times as many violent deaths as in 1970. The figure for 1989 was five times that of 1970 , and the figure from 1991 is six and one-half times the number of violent deaths recorded at the beginning of the 1970s. Of course the population has grown in the last three decades (see Table 7) but not at the same pace as the homicide rate.

In his article "War Making and State Making as Organized Crime" (1985), Charles Tilly puts forth a bare-bones view of the process of state making. While his argument is fundamentally based on the European experience, it serves to remind us that every process of state making has an inevitable coercive dimension. ${ }^{52}$ Thanks to their monopoly on the means of coercion, states can focus on four basic tasks that Tilly describes in the following manner: 1) "war making," or the elimination or neutralization of external rivals; 2) "state building," or the elimination or neutralization of internal rivals; 3) "protection," or the elimination or neutralization of enemies of its supporters; 
and 4) "extraction," or the acquisition of resources to undertake the first three tasks (1985: 181).

Table 6

\begin{tabular}{|c|c|}
\hline \multicolumn{2}{|c|}{ Colombia: Total Violent Deaths, 1970-1997 } \\
\hline Year & Total Violent Deaths \\
\hline 1970 & 4,445 \\
\hline 1971 & 4,885 \\
\hline 1972 & 5,073 \\
\hline 1973 & 5,200 \\
\hline 1974 & 5,566 \\
\hline 1975 & 5,788 \\
\hline 1976 & 6,349 \\
\hline 1977 & 6,989 \\
\hline 1978 & 7,073 \\
\hline 1979 & 8,000 \\
\hline 1980 & 9,122 \\
\hline 1981 & 10,713 \\
\hline 1982 & 10,580 \\
\hline 1983 & 9,721 \\
\hline 1984 & 10,694 \\
\hline 1985 & 12,899 \\
\hline 1986 & 15,672 \\
\hline 1987 & 17,419 \\
\hline 1988 & 21,100 \\
\hline 1989 & 23,312 \\
\hline 1990 & 25,320 \\
\hline 1991 & 28,872 \\
\hline 1992 & 29,601 \\
\hline 1993 & 27,634 \\
\hline 1994 & 26,644 \\
\hline 1995 & 25,657 \\
\hline 1996 & 26,665 \\
\hline 1997 & 27,085 \\
\hline
\end{tabular}

Source: Colombian Commission of Jurists, Table 1, "Evolution of the situation of human rights and socio-political violence in Colombia, 1970-1997." 
Table 7

\begin{tabular}{c|c}
\hline \multicolumn{2}{c}{ Colombia: Population } \\
\hline Year & \# of Inhabitants (in thousands) \\
1970 & 23,132 \\
1980 & 29,719 \\
1990 & 34,970 \\
1999 (estimated) & 41,564 \\
\hline Source: Inter-American Development Bank, 1999 Annual Report (2000: 141). \\
\hline
\end{tabular}

These four activities depend on the state's ability to monopolize the concentrated means of coercion. The four functions cross and overlap; moreover, success at carrying out one generally reinforces the others. "Thus, a state that successfully eradicates its internal rivals strengthens its ability to extract resources, to wage war and to protect its chief supporters" (Tilly, 1985: 181). Inversely, we argue that the failure to carry out any one of these functions tends to weaken the capacity for success with the other three. A state like Colombia, which is not able to eliminate or neutralize its internal rivals, is also unable to eliminate or neutralize the enemies of its potential "supporters" (citizens) or to extract resources to carry out its basic functions. Thus, the state's inability to monopolize the means of force in society creates a vicious circle that weakens it further while powerful rivals to the state are created and consolidated (such as guerrilla and paramilitary groups and the private armies of the drug trade). These rivals exercise control over numerous areas of the country, throwing into question basic notions of state coherence and the rule of law.

In contrast with the rest of Latin America, the guerrilla experiments of the 1960s not only survived in Colombia but solidified. Moreover, in the 1970s and 1980s a new series of "second-generation" armed movements appeared (Pizarro, 1996a). The second- 
generation groups negotiated their reincorporation to civilian life during the first half of the 1990s, as did one of the 1960s-era groups, the EPL. At the same time, the two largest and best-armed guerrilla groups, the FARC and the ELN, remained active. ${ }^{53}$ These two groups have grown exponentially in the last two decades (see Table 8), confirming the loss of the state's monopoly on the use of force described above.

Table 8

Guerrilla Growth 1975-1995

Number of fronts (and number of men in arms, approximately)

\begin{tabular}{c|c|c}
\hline Group & $\mathbf{1 9 7 5}$ & $\mathbf{1 9 9 5}$ \\
\hline FARC & 8 & 65 \\
& $(960)$ & $(7,800)$ \\
\hline ELN & 3 & 35 \\
& $(360)$ & $(4,200)$ \\
\hline All Guerrilla Groups & 15 & 102 \\
& $(1,800)$ & $(12,240)$ \\
\hline
\end{tabular}

Sources: Number of fronts comes from Echandía (1999b: 102-103). The number of men in arms is calculated assuming each front has an average of 120 men.

On the other hand, there are the so-called "paramilitary" groups ${ }^{54}$-a label that covers a broad range of private vigilante groups of diverse social origin, which display different operational tactics. These groups range from peasants legitimately organized in "self-defense" against the guerrilla's predatory practices to random hired killers and mercenaries. There are also social "cleansing" groups (primarily in urban areas), death squads, and bands of right-wing rural guerrillas (put together in the style of the Nicaraguan "Contras"). The most notable process related to the development of paramilitary groups - apart from their unusual growth (they are estimated as increasing their ranks from 650 men in 1987 to 8,000 in 2000) $)^{55}$-has been the emergence of an organization attempting to centralize and control these unruly vigilante groups. Since the mid-1990s, the United Self-Defense Groups of Colombia (or AUC) have emerged as a 
coordinator of antiguerrilla forces (similar to the former Simon Bolivar Guerrilla Coordinating Group). The AUC serves as an umbrella organization for small and large vigilante groups acting with similar intentions: to combat the guerrillas and defend the "establishment" at all costs.

The preferred tactic of paramilitary groups has been to carry out massacres of large groups of people with the aim of terrorizing the population. ${ }^{56}$ They have also engaged in selective assassination and sporadic combat with the guerrillas. Paramilitary groups are estimated to have an armed presence in 409 municipalities (40 percent of all the municipalities in the country), mostly in rural areas of the departments of Antioquia (Urabá) and Córdoba, the departments which border the midsection of the Magdalena River, and north and south Santander. More recently, they have entered such cities as Barrancabermeja, Montería, Medellín, and Bogotá. Their participation in politics has not been limited to war: the groups have also exercised their influence through elections by supporting candidates for city council, mayor, Chamber of Deputies, and Congress. In the areas they control, paramilitary groups (like guerrillas) have become true "protostate" actors. According to one account they "safeguard local morality (in Tierralta, Córdoba, the local paramilitary commander gave the men one month to decide whether they would stay with their wives or their lovers), implement local development projects [...] and mete out the death penalty, without a trial, to thieves, prostitutes, homosexuals and drug addicts." $" 57$

Completing this portrait, Colombia has become fertile ground for the black market in weapons. In 1994, 3.5 million arms were thought to be in civilian hands. According to a more recent survey (Cuellar, 1997, cited in Rubio, 1999b: 212-13), 11 percent of Colombians said they possessed a firearm. This means that today, more than four and one-half million arms are circulating in the country. 
Tilly's description of "war-makers" and "state-makers" as "coercive and selfseeking entrepreneurs" (1985: 169) seems quite apt for explaining the interactions that take place today in Colombia between a semicollapsed state and "aspiring state-makers" like the guerrillas (especially the FARC) and the paramilitary groups (especially the AUC). All of these groups can be appropriately thought of as "coercive entrepreneurs" (Tilly, 1985) who exercise "coercive exploitation" in the regions they dominate and who compete among themselves for the monopoly on means of coercion. The war can be explained on the basis of the effort that each of these entrepreneurs makes in controlling or defeating his competitors in order to enjoy the advantages of power over a secure, expanding territory (Tilly, 1985: 172).

\section{d) The Loss of the State's “Normative” Capacity}

The state does not only have a coercive dimension from which it derives, according to Tilly, its extractive and bureaucratic-administrative apparatuses, but also has an important normative dimension that relies upon its monopoly on force but is not reducible to it. ${ }^{58} \mathrm{~A}$ democratic state not only claims a monopoly on violence in society but more importantly, claims that this monopoly is a necessary condition for effectively guaranteeing the rights and freedoms of the citizens under its jurisdiction. Force is, above all, an instrument used toward an essential end - the establishment of a certain degree of internal order. That order is the most important uncertainty reducing public good provided by the state, thus allowing the interaction of multiple social agents in a stable and predictable environment. ${ }^{59}$ In a democracy, the state offers a certain social order where, at a minimum, all citizens are equal before the law. This equality of treatment-which is not necessarily accompanied by equality of opportunity or influence-known as the rule of law $^{60}$ or the universal extension of civil rights and liberties, is crucial to democracy. 
In Colombia, the existence of the rule of law is put into question by the degree to which the state has lost its monopoly on violence. The degree of contraction of the state's capacity in this regard precedes, and is perhaps more serious than, its inability to provide certain services and satisfy certain basic material needs. O'Donnell's depiction of the process of erosion of some Latin American states seems apt to describe the Colombian case: "In these situations, ineffective states coexist with autonomous, also territorially based, spheres of power. States become ostensibly unable to enact effective regulations of social life across their territories and their stratification systems. Provinces or districts peripheral to the national center (...) create (or reinforce) systems of local power which tend to reach extremes of violent, personalistic rule [...] open to all sorts of violent and arbitrary practices" (1999a: 138).

The collapse of the Colombian state's normative capacity is evident in the paralysis of certain branches (such as the judiciary), the ineffectiveness of others (the police), and the open disfigurement of functions in others (the military). Yet the problem is not confined to these areas: it also affects a less tangible but equally important dimension of the state that relates to its capacity to act as society's normative center. The disappearance of state authority in some areas of the country has permitted the existence of entire regions (including northern Antioquia, a large portion of Cordoba, areas of Magdalena Medio, the cocaine-growing zones of the eastern foothills and Amazon basin, and the so-called "demilitarized zone") where guerrillas, paramilitary groups, and drug lords have organized "protostates" both in the coercive and normative senses of the word.

The situation in these regions, controlled by rival armed actors or enemies of the state, can be described in the following manner: "These are subnational systems of power that, oddly enough for most extant theories of the state and of democracy, have a territorial basis and an informal but quite effective legal system and that coexist with a regime that, at least at the center of national politics, is polyarchical" (1999b: 314). These 
regions, the majority of which are rural, are far from functioning as "polyarchies" or democracies in the regional and local sphere. National elections (that is, presidential and congressional elections) may function in a more or less transparent way. ${ }^{61}$ But local and regional elections generally are much less clean, free, and competitive; intimidation, threats, and the use of force play a very important role. ${ }^{62}$ As O'Donnell has pointed out, this situation "highlights the question of who represents and what is represented in the institutions of the national regime and, more specifically, of how one conceptualizes a polyarchical regime that may contain regional regimes that are not at all polyarchical" (199b: 315). The Colombian case not only shows concrete evidence of this type of paradox, it also demonstrates the necessity for theorizing about the situation's impact on democracy. Undoubtedly, "our theories must come to terms with [...] the extent to which a polyarchical regime coexists with a properly democratic rule of law (or an estado democrático de derecho)" (Ibid: 325).

The state's deterioration or partial collapse has many facets. On the one hand is its incapacity to protect citizens from the aggression unleashed by its own agents or rivals. Yet the state not only has an obligation to protect its citizens; it must also punish those who attack them. If there is no investigation or punishment of abuses, the state fails to keep one of its most important promises. ${ }^{63}$ Impunity is, therefore, the other face of the state's incapacity. Impunity goes hand in hand with the other phenomena we have included here as symptoms of the state's erosion and "partial" collapse. Levels of criminality skyrocket when the state is incapable of preventing or containing them. At the same time, criminal organizations charged with taking justice "into their own hands" appear. According to Juan Méndez, "The emergence of a variety of violent criminals who are not clearly identified as state actors is also a salient feature of this picture [of lawless state violence]. Private armies and vigilante squads complicate the matter of assigning responsibility. It is not always clear that their actions are conducted under color of 
authority, or even that they are officially tolerated, although in certain regions evidence to that effect is not lacking. Yet, even if no policy exists of encouraging these actions, their existence and growth demonstrate a signal weakness in the ability of the state to keep peace and maintain order" (1999a: 21).

The weakness of state institutions in protecting citizens from potential abuses of their rights-joined with its inability to punish the guilty and provide effective mechanisms for conflict resolution-is undoubtedly one of the biggest threats to democracy in Colombia and in the rest of Latin America. Much of this weakness is attributable to the deplorable situation of the justice system throughout the continent. In nearly all of Latin America, the central problem of the justice system is its lack of independence in relation to the executive branch. In Colombia, the problem of judicial independence was solved, thanks to the National Front pacts that put into effect a cooptative system for naming judges and magistrates that guaranteed their autonomy in relation to politicians for many years (until 1991). Nevertheless, along with the rest of Latin America, Colombia shares a need to modernize its justice system and adapt it to new situations and changing problems. Throughout the region, the judiciary suffers from a lack of budgetary support, technical and administrative backwardness, and case backlogs. Yet the greatest problem seems to be that its physical capacity to deal with social conflict-and particularly with conflicts that tend to be violent-is completely overwhelmed. The judiciary is overwhelmed for clear reasons: first, since the early 1980s the country has experienced a real increase in levels of criminality associated with both the growth in guerrilla groups and the explosion in drug trafficking. Second, the impact of corruption, intimidation, threats, and violence by armed actors (in particular by drug traffickers against members of the judiciary) has been devastating.

The statistics presented by Mauricio Rubio in evidence of this trend are extremely alarming. In 1987, following the assassination of 53 members of the judiciary, "a survey 
of judges revealed their worry about the 'insecurity of members of this branch.' 25.4 percent of those surveyed stated that they or their families had been threatened as a result of their official activities. [...] Judges have been more affected by violence than other citizens, even more than those who live in the most violent areas of the country and more than members of the armed forces" (Rubio, 1999: 213-14). This systematic attack on members of the judiciary partly explains the Colombian state's growing inability to punish those who are guilty of abuses and to provide justice. Systematic intimidation, along with threats and attacks on judges throughout the country, represent a fundamental cause of the process of state deterioration described above. More than any other sector of the state, the judiciary has truly been besieged during the last two decades.

The deterioration of the state's ability to provide justice is not an isolated fact. As Rubio has shown, there is "a negative relationship between violence, measured by the homicide rate, armed groups and various indicators of performance in the area of penal justice. In the last two decades, the Colombian homicide rate has more than quadrupled. The influence of the main armed organizations has increased in a parallel fashion. During the same period, the penal system's capacity to investigate homicides has been reduced to one-fifth of what it was previously" (Rubio, 1999: 214-15).

\section{TABLE 9}

\begin{tabular}{l|c|c}
\hline \multicolumn{3}{c}{ Colombia: Levels of Impunity } \\
\hline & 1960s-1970s & $1990 s$ \\
\hline Proportion of homicides that lead to the arrest of suspects & $>60 \%$ & $<20 \%$ \\
Proportion of homicides that lead to trial & $>35 \%$ & $<6 \%$ \\
Proportion of homicides that end with conviction & $>11 \%$ & $<4 \%$ \\
\hline
\end{tabular}

Source: Rubio (1999: 215). 
These alarming rates of impunity have continued to worsen, despite the judicial reform launched by the 1991 constitution and despite the enormous fiscal effort made since the early 1990s in terms of expenditures for justice. ${ }^{64}$ With rates of impunity that pass 96 percent, ${ }^{65}$ we can undoubtedly affirm that the judicial apparatus and the state's normative capacity have collapsed in Colombia.

\section{Conclusion}

The Colombian case proves that democracy's various dimensions can evolve at different paces, and sometimes even in opposing directions. It is therefore not accurate to speak of advances or setbacks in democracy as a whole, because a single case may reveal advances in some dimensions alongside setbacks in others. Moreover-and this is perhaps one of the most troubling findings of this study-it is possible for efforts that enhance some aspects of democracy (i.e., opening the electoral arena) to have a negative impact on its other crucial dimensions (i.e., effective governance). For these reasons, it is important to remain aware of the trade-offs involved in any major democratization effort.

During the last decade and a half, Colombia has witnessed both an improvement in the dimensions of political participation and contestation and a severe deterioration in the dimensions related to effective protection of civil liberties and subordination of the military. Consequently, the Colombian political regime is difficult to classify, since it is neither a full democracy nor an authoritarian regime. The term "semidemocracy" seems most appropriate to us. Yet we would also point out that the restrictions that made the Colombian regime semidemocratic during the second half of the twentieth century have changed in nature. Between 1958 and 1986, restrictions were placed mostly on the competitive dimension of democracy. From the mid-1980s onward, the regime's shortcomings stem more clearly from the weakness of the state, the emergence of 
powerful armed actors (guerrillas and paramilitary groups), and the absence of the rule of law. Thus, we have classified Colombia as a "besieged democracy."

Searching for an explanation for this recent process of democratic erosion, we have built an argument that hinges mainly on political variables, even as it takes into account the enormously deleterious impact of drug trafficking on the Colombian state, society, and politics. At the regime level, we claim that it is no longer the system's "closed" nature that affects prospects for democratic consolidation, but instead the excessively lax rules of the game created during a long process of political reform that began in the mid-1980s and culminated with the new 1991 Constitution. This set of rules, resulting from what we have called the "logic of incorporation," has created additional incentives for party fragmentation, leading to an extremely atomized and personalistic party system that makes the task of effective governance even more difficult.

Yet at another level, we argue that the Colombian state has undergone a severe erosion that led to its partial collapse in the late 1980s. This collapse is partial in the geographical sense and in the sense that while some state apparatuses (the bureaucracy, the technocracy, the administration, the representative bodies) have retained certain coherence and capacity to act, other crucial branches have either collapsed (the judiciary), have become almost totally ineffective (the police) or have become totally disfigured in relation to their original functions (the armed forces). This "partial collapse" of the state is the result of challenges posed by very powerful criminal organizations (the drugdealing cartels) upon a state that was historically weak to begin with and had been confronting a guerrilla insurgency for over three decades.

Theoretically, we aim to emphasize the role of the state and find a proper place for it in discussions of the conditions and prospects for democracy, not only in Colombia, but other countries in the region. We have presented sufficient evidence to sustain our thesis about the partial collapse of the Colombian state, particularly in regard to its 
normative and coercive dimension. What seems evident in the Colombian case is the absence of a state in which, according to Kriegel's summation, "the sovereign's confiscation of all acts of war, his monopoly on the sword of justice, brings about individual security by means of the rule of law". ${ }^{66}$ And without a solid, democratic rule of law, democracy becomes impossible. The absence of a properly democratic rule of law not only threatens citizens' individual security and the exercise of minimal human and civil rights, it calls into question the dimensions of participation and competition that characterize all democratic political regimes.

In the best of cases, the state's glaring incapacity to provide security and justice leads to a paradoxical situation in which democratic rights (participation and competition) are respected, while democracy's liberal components (human rights and civil liberties) are systematically violated. Finally, without a doubt, the absence of effective guarantees on the exercise of basic human and civil rights-joined with an excess of autonomy and prerogatives granted to the military-end up affecting the participatory and representative dimensions of democracy. In other words, the very existence of polyarchy-using the term in its most minimal and procedural sense-ends up being threatened by the absence of a properly democratic rule of law.

Clearly, the reconstruction of the rule of law is the sine qua non for consolidation of Colombia's political democracy. Nevertheless, as difficult as it may sound, we propose that these two tasks be carried out not sequentially but simultaneously. We therefore do not argue for the rebuilding of the state as a priority that should precede democracy. Such an exercise could lead to the reconstruction of an authoritarian state that would be hostile to the democratic order or, even worse, to the reconstruction of a "mafioso" state as seems to have been the case in Fujimori's Peru. The struggle to rebuild the state must be closely tied to the struggle to rebuild and deepen democracy. In short, the goal is to rebuild authority without authoritarianism. The final result must be a democratic state 
whose central authority is reconstructed while the means to control that authority and avoid any excesses in its exercise are strengthened at the same time. 


\section{Endnotes}

1 "Most analysts have viewed Colombia since 1958 as a qualified democracy, using adjectives such as 'controlled,' 'oligarchical,' 'traditional bipartisan elitist,' 'near polyarchy,, or 'restricted'” (Hartlyn and Dugas, 1999: 251).

2 Our inspiration comes, of course, from the title of Ron Archer's article (1995).

3 For a discussion, see Posada-Carbó (1996).

4 According to Mainwaring, "A semidemocratic government or restricted democracy refers to a civilian government elected under reasonably fair conditions, but with significant restrictions in participation, competition, and/or the observance of civil liberties" (1999:14).

5 The decision to classify the Colombian regime as "democratic" between 1974 and 1990 is somewhat questionable, given that many of the formal and informal restrictions put in place by the National Front continued after 1974 and were not abolished until the new constitution was ratified in 1991. Despite this fact, we basically agree with the classification of Colombia as semidemocratic during most of the second half of the twentieth century.

6 Given the difficulties of creating more complex indices to measure the various dimensions of democracy, Mainwaring recommends utilizing the data produced by Freedom House since 1972. Every year, Freedom House assigns each country a grade between 1 (the best) and 7 (the worst) and measures its performance on two aspects: political rights and civil liberties. For more information on Freedom House's methodology and sources, and for the conceptual distinction between political rights and civil liberties, see http://freedomhouse.org. Although we agree with some of Munck and Verkuilen's criticisms (2001) of Freedom House's approach, it can still be utilized as an approximation (albeit imperfect) of the dimensions we are interested in considering in this paper. Moreover, the fact that Freedom House has sought to measure the quality of democracy from 1972 to the present is one argument in support of their work. Such long-term series of data are difficult to find among the attempts to measure democracy.

${ }^{7}$ This theme will be developed in more detail in the second section of this paper. See also O'Donnell (1999:143).

8 "The claim of liberal democracies to be liberal democracies rests on the claim that they have both wellestablished and also accessible procedures for protecting the liberties of individual citizens," Alan Ware (1992), as quoted by O'Donnell (1999a), footnote 16, p. 156 (emphasis is ours).

9 Our list of attributes coincides with many contemporary definitions of democracy as understood in its liberal, representative, and procedural version. See Collier and Levitsky, 1997; Mainwaring, 1999; and Mainwaring, Brinks, and Pérez-Liñán, 2001. These four basic requirements condense the list proposed by Dahl thirty years ago, in his study of polyarchy (1971).

10 The best study of the period is by Hartlyn (1988).

11 Following the 1968 constitutional reform (through which the National Front was dismantled), restrictions on competition at the local level were lifted in 1970. Restrictions that limited competition in congressional and presidential elections were eliminated in 1974. The rule requiring parity composition (power sharing) in the executive branch was formally extended until 1978 and practiced informally thereafter for eight more years, until 1986. At the same time, the rule requiring parity composition of the judicial branch remained in place until 1991 - that is, for 33 years.

12 For an explanation of the classification of guerrilla movements in two generations, see Pizarro (1996a).

13 Today, only two guerrilla groups remain active-the Revolutionary Armed Forces of Colombia, or FARC (created in 1964) and the National Liberation Army, or ELN (created in 1965). 
14 This era of political reform began with approval of the first policies promoted by the Belisario Betancur government and ended with the writing of the new constitution. In 1985, the first project to be approved was Law 58, also known as the "Basic Statute of Political Parties." Next came municipal reforms and the popular election of mayors, approved in 1986 and implemented in 1988. Finally, the 1991 constitution eliminated all restrictions and broadened channels and opportunities for political participation and competition. For a summary of the reforms related to parties see Dugas (2000). For an evaluation of political reform see Pizarro and Bejarano (2001). For a deeper analysis of reforms included in the 1991 constitution see Dugas (1993), Gómez (2000), and Bejarano (2001).

15 A discussion of diminished subtypes of democracy is found in Collier and Levitsky (1997).

16 Defined as "the rights and obligations of the legal person as a member of society" (O'Donnell, 1999b: 308).

17 These statistics are from Zuluaga (1999: 50-53).

18 The reasons include the history of the formation of the state in the nineteenth century and its long civilian tradition, as well as the strength of the Liberal and Conservative parties for more than a century and a half. For more on the Colombian military see Leal (1984) and Dávila (1998).

19 See Pizarro (1996b).

20 This date marks a breaking point in the country's recent history. In 1977, organized labor led a broad movement of social protest that culminated in September of that year with a nationwide general strike. Reacting to the mobilization, the military sent a memorandum to President López Michelsen asking for a "strong hand" against social unrest. The state's response was a hardening that became evident at the start of the Turbay administration (1978-82), when the Security Statute was issued.

21 Limitations on this "civil" or "liberal" dimension of democracy (which implies the full exercise of citizenship) can be conceived from a socioeconomic perspective, as in the work of Eric Hershberg (1999: 292). Hershberg argues that the exercise of citizenship is incomplete or impractical when there is also socioeconomic exclusion or inequality. We would argue - not in a contradictory, but complementary spirit - that there is another dimension of citizenship that has not been adequately considered, which is related to its most juridical or normative component and is defined as the universal access to certain basic rights (such as the right to life, to physical integrity, and to safety), independently of the distribution of social and economic rights and opportunities.

22 It would be worthwhile to classify Colombian municipalities according to Oquist's methodology (1978), in order to distinguish municipalities where a single party was hegemonic or in control from those that experienced real two-party competition between 1930 and 1946. The big difference is that today an armed actor in the conflict-rather than either of the two traditional parties-would exercise control or hegemony. In fact, the struggle for control and hegemony among armed actors has greatly diminished the space for true political competition, above all at the local level. For a discussion of the impact of armed conflict on local elections, see Dávila and Corredor (1998) and Miguel García (2000a and b).

23 As Mainwaring points out (1999: 37), it is important to distinguish between the processes of breakdown and erosion of democracy. The Colombian case is very clearly one of gradual erosion, or "slow death" of democracy (O'Donnell) and not one of an unexpected return to authoritarianism.

24 Between August 1989 and April 1990, three presidential candidates were assassinated. Among these was a Liberal candidate with strong chances of reaching the presidency: Luis Carlos Galán. After Galán's assassination, in which top leaders of the drug trade supposedly participated, the Barco government unleashed a major offensive against drug trafficking (the "war on drugs"). This in turn led to a long and bloody wave of "narcoterrorism" against the Colombian government and people.

25 See López Michelsen’s interview with Enrique Santos Calderón’s in López Michelsen (2001). 
26 See the interview with Gilberto Vieira, ex-general secretary of the Colombian Communist Party, June 1996, Bogota.

27 Although all the guerrilla groups fed upon this radicalization of the anti-National Front critique, the M19 (which took its name precisely from the 1970 elections) was the clearest representative of this segment of the Left-opposing the antidemocratic restrictions of the institutional pact and speaking out in favor of a democratic opening.

28 Perhaps the most influential text at the time was Francisco Leal Buitrago's "Crisis of the Two-Party Regime" (1984).

29 The term O'Donnell uses for these political practices, which are so common throughout Latin America.

30 Moreover, many recent studies show that the independent ("untied") urban vote has increased, at least in certain exceptional circumstances, especially but not exclusively in presidential elections. In addition, political, ethnic, and religious minorities-which don't base their vote on clientelism or in the private use of public resources-have had increasing access to the representative system since 1991. See Bejarano and Dávila (1998).

31 This is the term we use in Pizarro and Bejarano (2001).

32 A document recently commissioned by the Ministry of the Interior, authored by a prestigious group of consultants (Arturo Valenzuela, Josep Colomer, Arend Lijphart, and Matthew Shugart), actually maintains that "[...] Colombia's current electoral system is the most 'personalistic' in the world" (Informe de la Consultaría Internacional, 1999: 237). The Colombian electoral system is based on a system of proportional representation (Hare system) with closed and blocked lists. But - and herein lies the main problem - each party or movement recognized by the National Electoral Council can put forth an indefinite number of lists or candidates in each electoral district. This system, in a context of party disorganization, leads to a widespread "war of residuals" that aims to obtain the largest possible number of seats with the least number of votes. That is, each party or movement presents multiple lists in various electoral districts, resulting in a situation where "it splits its own vote, giving up the possibility of obtaining seats by quotient (but maximizing) the possibility of obtaining them by residual" (Gutiérrez, 1998: 222).

33 According to current laws governing parties, a party needs the support of one member of Parliament, 50,000 votes or 50,000 signatures to be legally recognized by the National Electoral Council. Thanks to this lax requirement, any electoral micro-enterprise (whether a Liberal or Conservative personalist faction or a "third force") can have free access to television, obtain state financing, and indiscriminately gather endorsements for electoral campaigns.

34 This argument has been put forth by Fernán González $(1989,1997)$.

35 The argument related to "partial collapse" of the state is inspired by Paul Oquist's pioneering work (1978), which uses a similar argument to explain the party violence (Violencia) of the mid-twentieth century.

36 Recently, writings about this type of failed state have proliferated. While this literature should be taken into account, most authors fail to delineate the differences among cases under consideration and they indiscriminately and superficially apply such key concepts as fragile, weak, failed or failing. In our opinion, the meaning of each of these adjectives should be defined more clearly and they should be used with greater precision and consistency.

37 In contrast with the period of the Violencia studied by Oquist (1978), at present neither parliamentary nor electoral institutions have experienced the process of collapse that they did in the 1940s and 50s. Therefore, we believe that the current process of "partial collapse" of the state is even more limited than the one that occurred fifty years ago. It is important to note that the 1993 reforms had well-known positive effects on the Colombian police. The recuperation of the police has demonstrated that it is indeed possible 
to intervene and reverse the process of state erosion. At the same time, serious problems still exist today, including militarization of the rural police, for example, and the institution's almost exclusive focus on tasks related to public order and antidrug efforts while neglecting tasks related to crime prevention, safety, and the well-being of citizens.

38 See, for example, the work of Alfredo Molano.

39 Historians have widely documented this constant. See the work of Malcolm Deas, Marco Palacios, Eduardo Posada-Carbó, Jorge Orlando Melo, and Fernán González.

40 See Pizarro (1991 and 1996a).

41 Here we should note our slight disagreement with Mauceri. While he maintains that every member of the Colombian elite chose the strategy of privatizing the counterinsurgency war, we strongly believe that the Colombian elite was more complex and that it demonstrated at least two different responses to the guerrillas. See Mauceri (2001: 1-2 and 11-14).

42 See López (1998) and the studies by López and Camacho (2001) and Gutiérrez (2001).

43 This was the case with Carlos Lehder and his National Latino Movement.

44 In the early 1980s, the Liberal Party elected Pablo Escobar as a substitute representative to the Chamber of Deputies.

45 The best-known case, but certainly not the only one, was the financing of Ernesto Samper's 1994 presidential campaign with money from the Cali Cartel.

46 The drug trade's violent impact on politics became evident with the 1984 assassination of Justice Minister Rodrigo Lara Bonilla, who openly opposed the inclusion of drug traffickers in political parties. A series of political assassinations followed this one, including the murder of Attorney General Carlos Mauro Hoyos, and reached a peak with the assassination of Liberal Party presidential candidate Luis Carlos Galán in August 1989. The Barco government's response was to declare a "war on drugs." A wave of urban "narcoterrorism" followed that aimed to sway state and public opinion against extradition of drug traffickers to the United States. Although political assassinations and narcoterrorism have decreased since Pablo Escobar's death in 1993, the organizations involved in the drug trade retain an enormous capacity to pressure the Colombian state through corruption, threats, and assassination of all types of public officials. Victims have included prison guards, police officers, judges, magistrates, members of the military, and politicians at all levels.

47 For a discussion see Mason (2000).

48 This trend toward militarization of the fight against drugs became clear with the US Congress's appropriation of funds in 2000 for the "Plan Colombia."

49 See Bejarano (1994).

50 Levels of violence in Colombia are unusually high, even compared to other Latin American countries. Only El Salvador's homicide rate surpassed that of Colombia in the 1990s. See Levitt and Rubio (2000: 3-4).

51 See http://eltiempo.terra.com.co/13-10-2000/judi 1.html According to Paul Oquist (1978:11), between 1946 and 1966, the conflict "left at least 200,000 people dead." Thus between 1980 and 2000 in Colombia, two and one-half more people died violently than during the Violencia. According to the Institute of Legal Medicine report, "the tendency in the last quarter-century was an increase, with an approximate annual average of 25,000 homicides in the last decade." The majority of the victims were between 18 and 44 years of age. Firearms and knives were the most common weapons used. Homicide has become the "number one cause of death in Colombia, responsible for 20 percent of deaths among the general population" and 25 percent of deaths among men. There has also been a dramatic increase in phenomena associated with 
violence, such as injuries, mental problems, death of a parent or spouse, and forced displacement of the population.

52 Michael Mann refers to this dimension as the state's "despotic power." See Mann (1984).

53 On the FARC, see Rangel (1999). The work of Camilo Echandía (1999 a and b) is useful for its observations on the process of guerrilla expansion in Colombia.

54 The best translation of the Colombian term paramilitares is "vigilantes" in the sense that they are organized, extralegal groups that take the law into their own hands. See Cubides (1999).

55 In 1987, the government revealed for the first time before Congress the existence of 138 self-defense groups whose membership included 650 men. Today, it is estimated that these groups have a membership of 6,000 to 8,000 combatants. Of these, 30 percent came from the ranks of the guerrillas, more than 1,000 are former members of the military and police (including former officers and noncommissioned officers). Between 1998 and 2000, according to the Ministry of Defense, "these groups grew by 81 percent, five times more than the guerrillas' growth during the same period." This information comes from "La guerra de los paras," Semana.com, April 5, 2001, p. 3.

56 In 2000, they assassinated 988 unarmed civilians, according to Ministry of Defense data. Statistics on massacres during the second half of the 1990s are found in Zuluaga (1999). There were 75 massacres in 1994 and 145 in 1998.

57 "La guerra de los paras," in Semana.com, April 5, 2001, p. 3.

58 This normative (or "legal") dimension of the state has been the subject of some of Guillermo O'Donnell's recent work. See 1999 a and b in particular.

59 This order, as Mann (1984) and also O'Donnell (1999a) have affirmed, is never egalitarian or socially impartial. Whatever its ideological stamp, it supports and contributes to the reproduction of asymmetrical power relationships. Nevertheless, "it is still an order, in the sense that multiple social relations are carried out on the basis of stable norms and expectations" (O’Donnell, 1999a: 135). Authors such as Finnis and Krygier also highlight the importance of predictability. The rule of law, when working properly, "brings definition, specificity, clarity and thus predictability into human interactions (John Finnis, 1980, as quoted by O'Donnell, 1999b: 334). “At a bare minimum...the point of the rule of law-and its great cognitive and normative contribution to social and political life-is relatively simple: people should be able to rely on the law when they act" (Krygier, as quoted by O'Donnell, 1999b: 335). [Emphasis is ours.]

60 According to O'Donnell, a "democratic rule of law" should be defined as "the legally based rule of a democratic state. This entails that there exists a legal system that is itself democratic, in three senses: first it upholds the political freedoms and guarantees of polyarchy; second, it upholds the civil rights of the whole population; and third, it establishes networks of responsibility and accountability that entail that all agents, public and private, including the highest placed officials of the regime, are subject to appropriate, legally established controls of the lawfulness of their acts. $\{\ldots\}$ As long as it fulfills these three conditions, such a state is not just a state ruled by law; it is a democratic legal state, or an estado democrático de derecho" (O’Donnell, 1999b: 318-19).

${ }^{61}$ Although it is worth remembering that during the 1990 presidential campaign in Colombia, three presidential candidates were assassinated: Luis Carlos Galán, Carlos Pizarro, and Bernardo Jaramillo. Another, Jaime Pardo Leal, had been assassinated two years earlier, in 1987.

${ }^{62}$ For a discussion of the distortions that violence causes in local elections, see Dávila and Corredor (1998) and the work of Miguel García (2000 a and b).

${ }^{63}$ In Juan Méndez's words, “those whose duty it is to stop those murders and other abuses do little to bring the perpetrators to justice and even less to discipline them administratively. [...] These crimes go 
generally uninvestigated and regularly unpunished, and [...] a clear duty on the part of the state is thus violated" (1999a: 20).

64 The average expenditure on justice, expressed as a percentage of GDP, increased from 0.5 percent between 1970-79, to 0.6 percent between 1980-89 and to 0.99 percent between 1990-98. That is, spending has doubled in the last thirty years. The annual real rate of growth was 4.36 percent in the $1970 \mathrm{~s}, 5.8$ percent in the 1980s and 11.11 percent in the 1990s. The crisis in the justice system and the 1991 constitution explain the notable increase of the 1990s. See Ariza et al. (2000: 77-78).

65 Other data on impunity and the crisis in the justice system are found in García and Uprimny (1999); Ariza et al. (1999) and Ariza, et al. (2000). See also Maurcio García and Boaventura de Sousa Santos (2001).

66 Kriegel, quoted in Posada-Carbó (1998: 14). 


\section{Bibliography}

Altman Olin, David, and Aníbal Pérez-Liñán. 2000. "Assessing the Quality of Democracy: Freedom, Competitiveness and Participation in 18 Latin American Countries." Unpublished manuscript.

Archer, Ronald. 1995. "Party Strength and Weakness in Colombia's Besieged Democracy." In Scott Mainwaring and Timothy R. Scully (eds.), Building Democratic Institutions. Party Systems in Latin America. Palo Alto, CA: Stanford University Press.

Ariza Libardo, Antonio Barreto and Manuel Iturralde. 2000. "La administración de justicia." In Luis Alberto Restrepo (ed.), Síntesis 2000. Anuario Social, Político y Económico de Colombia. Bogotá: IEPRI-Fundación Social-Tercer Mundo Editores.

Ariza Libardo, Antonio Barreto, and Olga Lucía Gaitán. 1999. "La justicia en 1998." In Luis Alberto Restrepo (ed.), Síntesis 1999. Anuario Social, Político y Económico de Colombia. Bogotá: IEPRI-Fundación Social-Tercer Mundo Editores.

Bejanano, Ana María. 2001. "The Constitution of 1991: An Institutional Evaluation Seven Years Later." In Charles Bergquist, Ricardo Peñaranda, and Gonzalo Sánchez (eds.), Violence in Colombia 1990-2000, Waging War and Negotiating Peace. Wilmington, DE: Scholarly Resources Inc.

. 1994. "Recuperar el estado para fortalecer la democracia." In Análisis Político, No. 22, mayo a agosto.

Bejanano, Ana María and Renata Segura. 1996. "El fortalecimiento selectivo del Estado durante el Frente Nacional.” Controversia, No. 169, Segunda Etapa, noviembre.

Bejanano, Ana María and Andrés Dávila (eds.). 1998. Elecciones y Democracia en Colombia, 1997-1998. Bogotá: Universidad de los Andes-Departamento de Ciencia Política-Fundación Social-Veeduría Ciudadana a la Elección Presidencial.

Cavarozzi, Marcelo. 1991. "Más allá de las transiciones a la democracia en América Latin.” In Revista de Estudios Políticos, No. 74, octubre-diciembre, Madrid.

Collier, David, and Steven Levitsky. 1997. "Democracy with Adjectives. Conceptual Innovation in Comparative Research.” World Politics 49 (3) (April): 430-51.

Comision Colombiana de Juristas. 2000. Panorama de derechos humanos y derecho humanitario en Colombia. Informe de avance sobre 2000. Bogota: Comisión Colombiana de Juristas.

Coppedge, Michael, and Wolfang H. Reinicke. 1990. "Measuring Polyarchy." Studies in Comparative International Development 25 (1). 
Cubides, Fernando. 1999. "Los paramilitares y su estrategia." In Malcolm Deas and Maria Victoria Llorente (eds.), Reconocer la guerra para construir la paz. Bogotá: Ediciones Uniandes-Editorial Norma.

Dahl, Robert. 1971. Polyarchy. Participation and Opposition. New Haven, CT: Yale University Press.

Dávila, Andrés. 1998. El juego del poder. Historia, armas y votos. Bogota: UniandesCEREC.

Dávila, Andrés and Ana María Corredor. 1998. "Las elecciones del 26 de octubre: ¿Cómo se reprodujo el poder local y regional?" In Ana María Bejarano and Andrés Dávila (eds.), Elecciones y Democracia en Colombia, 1997-1998. Bogotá: Universidad de los Andes-Departamento de Ciencia Política-Fundación Social-Veeduría Ciudadana a la Elección Presidencial.

Dugas, John. 2000. "Sisyphus in the Andes? The Quest for Political Party Reform in Colombia." Unpublished manuscript.

(editor). 1993. La Constitución de 1991: ¿Un pacto político viable? Bogotá: Universidad de los Andes-Fondo Editorial CEREC.

Echandía, Camilo. 1999a. El conflicto armado y las manifestaciones de violencia en las regiones de Colombia. Bogotá: Presidencia de la República, Oficina del Alto Comisionado para la Paz.

1999b. "Expansión territorial de las guerrillas colombianas: geografía, economía y violencia." In Malcolm Deas and María Victoria Llorente (eds.). Reconocer la guerra para construir la paz. Bogotá: CEREC-Ediciones Uniandes-Editorial Norma.

Garcia, Mauricio and Boaventura de Sousa Santos. 2001. El caleidoscopio de las justicias en Colombia. Bogotá: Colciencias, 2 Vols.

and Rodrigo Uprimny. 2000. "El nudo gordiano de la justicia y la guerra en Colombia." In Alvaro Camacho Guizado and Francisco Leal Buitrago (eds.), Armar la paz es desarmar la guerra. Bogotá: CEREC-DNP-PNUD, FESCOL, IEPRI, Presidencia de la República.

Garcia, Miguel. 2000a. "Elección popular de alcaldes y terceras fuerzas. El sistema de partidos en el ámbito municipal, 1988-1997." Análisis Político. No. 14, septiembre-diciembre.

2000b. "Elecciones municipales. Bipartidismo, un paso atrás." UN Periódico. No. 16, Noviembre 19.

Gómez, Juan Gabriel. 2000. "Sobre las constituciones de Colombia (incluida la de papel)." In Instituto de Estudios Políticos y Relaciones Internacionales (IEPRI), Colombia: Cambio de siglo. Balances y Perspectivas. Bogotá: Planeta Colombiana Editorial S.A. 
Gonzalez, Fernán. 1989. "Aproximación a la configuración política de Colombia." Controversia. Nos. 153-154.

. 1997. Para leer la política. Ensayos de historia política colombiana. 2 Vols. Bogotá: CINEP.

Gutiérrez, Francisco. 1998. "Rescate por un elefante. Congreso, sistema y reforma política." In Ana Maria Bejarano and Andres Davila (eds.), Elecciones y democracia en Colombia 1997-1998. Bogota: Universidad de los Andes.

. 2001. "Organized Crime and the Political System in Colombia (1978-1998)," paper presented at the conference "Democracy, Human Rights, and Peace in Colombia," The Kellogg Institute for International Studies, University of Notre Dame, March 26-27, 2001.

Hartlyn, Jonathan. 1988. The Politics of Coalition Rule in Colombia. Cambridge: Cambridge University Press.

Hartlyn, Jonathan, and John Dugas. 1999. "Colombia: the Politics of Violence and Democratic Transformation." In Larry Diamond, et al. (eds.), Democracy in Developing Countries: Latin America. 249-307. Boulder: Lynne Rienner.

Hershberg, Eric. 1999. "Democracy and Its Discontents: Constraints on Political Citizenship in Latin America." In Howard Handelman and Mark Tessler (eds.), Democracy and its Limits: Lessons from Asia, Latin America and the Middle East. Notre Dame, IN: University of Notre Dame Press.

Inter-American Development Bank. 2000. Annual Report 1999. Inter American Development Bank.

Kline, Harvey. 1995. Colombia: Democracy Under Assault. $2^{\text {nd }}$ ed., Boulder, CO: Westview.

Leal, Francisco. 1984. Estado y política en Colombia. Bogotá: Siglo XXI Editores. and Andrés Dávila. 1990. Clientelismo. El sistema político y su expresión regional. Bogotá: Tercer Mundo Editores/IEPRI.

Levitt, Steven and Mauricio Rubio. 2000. "Understanding Crime in Colombia and What Can Be Done About It." Fedesarrollo: Working Paper Series - Documentos de Trabajo, Agosto, No. 20.

Lopez Michelsen, Alfonso. 2001. Palabras pendientes. Conversaciones con Enrique Santos Calderón. Bogotá: El Ancora Editores.

Lopez, Andrés. 1998. "Narcotráfico y elecciones: delincuencia y corrupción en la reciente vida política colombiana." In Ana María Bejarano and Andrés Dávila (eds.). Elecciones y Democracia en Colombia, 1997-1998. Bogotá: Universidad de los Andes-Departamento de Ciencia Política-Fundación Social-Veeduría Ciudadana a la Elección Presidencial. 
Lopez, Andrés and Alvaro Camacho. 2001. "From Smugglers to Drug-Lords to 'Traquetos': Changes in the Colombian Illicit Drug Traffick." Paper presented at the conference "Democracy, Human Rights, and Peace." Kellogg Institute for International Studies, University of Notre Dame, March 26-27, 2001.

Mainwaring, Scott. 1999. "Democratic Survivability in Latin America." In Howard Handelman and Mark Tessler (eds.), Democracy and its Limits: Lessons from Asia, Latin America and the Middle East. Notre Dame, IN: University of Notre Dame Press.

Mainwaring, Scott, Daniel Brinks, and Aníbal Pérez-Liñán. 2001. "Classifying Political Regimes in Latin America, 1945-1999." Unpublished manuscript.

Mann, Michael. 1984. "The Autonomous Power of the State." Archives Européenes de Sociologie XXV (2).

Mason, Ann C. 2000. "The Colombian Security Crisis: International Causes and Consequences of a Failing State." Paper presented at the Research Workshop "Civil Conflict in Colombia: The Challenges of Peacemaking and Reconciliation," Princeton University, September 22.

Mauceri, Philip. 2001. "State, Elites and Counter-Insurgency: Some Preliminary Comparisons Between Colombia and Perú." Unpublished manuscript.

Méndez, Juan. 1999a. "Problems of Lawless Violence: Introduction." In Juan E. Méndez, Guillermo O'Donnell and Paulo Sergio Pinheiro (eds.), The (Un)Rule of Law and the Underprivileged in Latin America. Notre Dame: University of Notre Dame Press.

. 1999b. "Institutional Reform, Including Access to Justice: Introduction." In Juan E. Méndez, Guillermo O'Donnell and Paulo Sergio Pinheiro (eds.), The (Un)Rule of Law and the Underprivileged in Latin America. Notre Dame: University of Notre Dame Press.

Ministerio Del Interior. 1999. Reforma Política. Un propósito de nación. Serie Documentos, No. 17, Bogotá: Ministerio del Interior.

Munck, Gerardo and Jay Verkuilen. 2000. "Conceptualizing and Measuring Democracy: Evaluating Alternative Indices.” Unpublished manuscript.

O’Donnell, Guillermo. 1999a. "On the State, Democratization and Some Conceptual Problems: A Latin American View with Glances at Some Postcommunist Countries." In Counterpoints. Notre Dame, IN: University of Notre Dame Press.

. 1999b. "Polyarchies and the (Un)Rule of Law in Latin America: A Partial Conclusion." In Juan E. Méndez, Guillermo O'Donnell, and Paulo Sergio Pinheiro (eds.), The (Un)Rule of Law and the Underprivileged in Latin America. Notre Dame, IN: University of Notre Dame Press.

Oquist, Paul. 1978. Violencia, Conflicto y Política en Colombia. Bogotá: Instituto de Estudios Colombianos - Biblioteca Banco Popular. 
Palacios, Marco. 2000. "La solución política al conflicto armado, 1982-1997.” In Alvaro Camacho and Francisco Leal (eds.), Armar la paz es desarmar la guerra. Bogotá: CEREC - DNP -PNUD, FESCOL, IEPRI, Presidencia de la República.

Pizarro, Eduardo. 1991. Las Farc 1949-1966: De la autodefensa a la combinación de todas las formas de lucha. Bogotá: IEPRI-Tercer Mundo Editores.

1996a. Insurgencia sin revolución. La guerrilla colombiana en perspectiva comparada. Bogotá: IEPRI-Tercer Mundo Editores.

. 1996b. "La reforma militar en un contexto de democratización política." In Francisco Leal, (ed.). In busca de la estabilidad perdida. Bogotá: Tercer Mundo Editores-IEPRI.

Pizarro, Eduardo and Ana María Bejarano. 2001. "La reforma política después de 1991: ¿Qué queda por reformar?" Paper presented at the Conference "Democracy, Human Rights and Peace in Colombia." Kellogg Institute, University of Notre Dame, March 26-27, 2001.

Posada-Carbó, Eduardo (ed.). 1996. Elections before Democracy: The History of Elections in Europe and Latin America. London: Macmillan Press Ltd.

. 1998. "Reflections on the Colombian State: In Search of a Modern Role." In Eduardo Posada-Carbó (ed.), Colombia: The Politics of Reforming the State. New York: St. Martin's Press.

Rangel, Alfredo. 1999. "Las Farc-Ep: una mirada actual." In Malcolm Deas and Maria Victoria Llorente (eds.), Reconocer la guerra para construir la paz. Bogotá: CEREC-Ediciones Uniandes-Editorial Norma.

Rubio, Mauricio. 1999. "La justicia en una sociedad violenta.” In María Victoria Llorente and Malcolm Deas (eds.), Reconocer la guerra para construir la paz. Bogotá: Ediciones Uniandes-CEREC-Editorial Norma.

Tilly, Charles. 1985. "War Making and State Making as Organized Crime.” In Peter B. Evans, Dietrich Rueschemeyer and Theda Skocpol (eds.). Bringing the State Back In. Cambridge: Cambridge University Press.

Valenauela, J. Samuel. 1992. "Democratic Consolidation in Post-transitional Settings: Notion, Process and Facilitating Conditions." In Scott Mainwaring, Guillermo O'Donnell, and J. Samuel Valenzuela (eds.). Issues in Democratic Consolidation: The New South American Democracies in Comparative Perspective. Notre Dame, IN: University of Notre Dame Press.

Wilde, Alexander. 1982. Conversaciones de caballeros. La quiebra de la democracia en Colombia. Bogotá: Ediciones Tercer Mundo.

Zuluaga, Jaime. 1999. "Sueños de paz. Realidades de la guerra." In Luis Alberto Restrepo (ed.). Síntesis '99. Anuario Social, Político y Económico de Colombia. Bogotá: IEPRI-Fundación Social-TM Editores: 45-54 